\title{
Leche amarga: Violencia y erotismo en la narrativa chilena del siglo XX (B ombal, Brunet, D onoso, Eltit), de Rubí Carreño Bolívar
}

Santiago: Editorial Cuarto Propio, 2007, 223 pp.

\author{
Luis Vaisman A. \\ Universidad de Chile. Santiago, Chile \\ luvaabra@ctcreuna.cl
}

ECHE amarga: Violencia y erotismo en la narrativa chilena de sigloXX (Bombal, L Brunet, D onoso, Eltit), "propone releer parte de la historia de la literatura chilena a partir de aquellos aspectos 'desagradables' que la primera crítica (acerca de los autores seleccionados) escamotea" (p. 5). Como señala la autora en la nota 6: "No es difícil imaginar que la presencia de inmaculadas mujeres de clase alta 'ardiendo de pasión', los deseos homoeróticos de los personajes, el modelo familiar de la madre prostituta, el padre homosexual de una niña andrógina, los incestos, asesinatos y violaciones, y la superposición de espacios que homologa el salón de la casa con el del burdel o el del dormitorio con la cárcel, y todos ellos con la patria, son los elementos de esta narrativa más visibles de lo que en Chile suele/debe quedar fuera de la foto familiar". Es, pues un proyecto de desplazamiento de los límites de la mirada oficial, escogiendo el margen, lo marginado, como foco iluminador del total. Y aunque menos hoy que ayer, es por ello todavía un proyecto polémico.

Para dar voz a lo silenciado, la autora hace dialogar los textos literarios escogidos "con el corpus individual y colectivo de los autores; con otros discursos sociales como la crítica (literaria), el periodismo y el discurso político y, finalmente, entre sí. Este procedimiento de lectura (dialógica, interdiscursiva, sincrónica y diacrónica)" permitirá "oír todas las voces que articulan el discurso erótico-violento" (6-7). La descripción detallada de la relación entre erotismo y violencia que, soterrada, metonimizada, metaforizada en esos textos es su principio generador, será la llave para abrir y desplegar ante los ojos de la crítica y ojalá- de la sociedad chilena esta visión acerca de nuestra historia literaria y nacional.

Un amplio espectro de perspectivas teóricas es atraído de manera sumamen- 
te competente, y perfectamente comprensible para cual quier lector culto, como marco de referencia e instrumental para el más cabal cumplimiento de los objetivos de esta investigación: antropología, historiografía, sociología, estudios de género, teoría literaria, crítica cultural confluyen en un estudio serio, riguroso, iluminador y profundamente conmovedor por la finura empática de la autora respecto del tema y por la calidad poética de su pluma.

Resultan particularmente destacables el lúcido examen de la propuesta de RenéG irard acerca de la elaboración mítico-literaria del fenómeno de la violencia y su relación con el deseo erótico, y el análisis desacralizador de las de H enri Bataille sobre el mismo asunto:

Tras leer a Bataille queda la sensación de que en su escritura dispersa y original, comentada ampliamente por el grupo Tel quel y reelaborada por escritores latinoamericanos como Sarduy y Elizondo, serevelan apreciaciones máso menos convencionales respecto al tema que a nosotros nos interesa: a pesar de la espectacular escena en la cual se desarrolla el pensamiento de Bataille respecto a la violencia y el erotismo (...): los espacios primigenios, el altar sacrificial y la particular dialéctica surrealista, hombre y mujer aparecen representando una obra conocida: él, un victimario autorizado por dios y los hombres y ella, una víctima abierta a una sexualidad masculina que se percibe a sí misma como sucia y agresiva (22).

La introducción del modelo de la cultura hacendada -y su variante urbana marginal- como imagen explicativa de la cómplice y complicada relación vícti$\mathrm{ma}$ /victimario(a) que es asumida alternativamente tanto por los hombres como por las mujeres no es el mérito menor de estelibro, y muestra sus frutos tanto en el análisis e interpretación de la relación interpersonal como en la social y política a nivel nacional.

Papel relevante cumplen numerosas citas como las ya mencionadas y al gún epígrafe, acierto de ironía en varios niveles, como el que inaugura la parte VI sobreEltit citando a Raquel Argandoña, queopera además como un buen ejemplo de condensación, según se define este procedimiento en la página 171, nota 5.

Por último, el papel del cuerpo en la escritura de D iamela Eltit como último reducto del signo, al desaparecer objeto de la violencia inseparable del ejercicio de la sexualidad, resulta particularmente impactante como cierre, a través de un texto estremecedor y remecedor de estereotipos, de un recorrido alucinante y agobiador que sitúa tanto la historia literaria de C hile como la otra, la historia de $\mathrm{C}$ hile a secas, en una perspectiva terrible, imposible ya de ignorar ni sublimar. 